\title{
Production of pepper and industrial tomato seedlings fertilized with biostimulants
}

\author{
Produção de mudas de pimentão e tomate industrial fertilizadas com bioestimulantes \\ Producción de plántulas de pimiento y tomate industrial fertilizadas con bioestimulantes
}

Received: 12/14/2020 | Reviewed: 12/18/2020 | Accept: 03/28/2021 | Published: 04/06/2021

\author{
João Eduardo Ribeiro da Silva \\ ORCID: https://orcid.org/0000-0002-1550-2447 \\ Universidade Federal de Uberlândia, Brasil \\ E-mail: johned87@yahoo.com.br \\ Roberta Camargos de Oliveira \\ ORCID: https://orcid.org/0000-0002-2432-0442 \\ Universidade Federal de Uberlândia, Brasil \\ E-mail: robertacamargoss@gmail.com \\ Jose Magno Queiroz Luz \\ ORCID: https://orcid.org/0000-0002-5712-7710 \\ Universidade Federal de Uberlândia, Brasil \\ E-mail: jmagno@ufu.br \\ Ariel Santivanez Aguillar \\ ORCID: https://orcid.org/0000-0003-2743-9147 \\ Universidade Federal de Uberlândia, Brasil \\ E-mail: ariel_trex89@hotmail.com \\ Ernane Miranda Lemes \\ ORCID: https://orcid.org/0000-0003-2895-9603 \\ Universidade Federal de Uberlândia, Brasil \\ E-mail: ernanefito@gmail.com
}

\begin{abstract}
Growth regulators such as biostimulants can promote positive changes in the plant physiological processes, being alternatives to help the seedlings development with high seedlings quality. Therefore, this study aims to evaluate the characteristics of industrial tomato and pepper seedlings fertilized with biostimulants. The experimental design was a randomized block design with six treatments and four replicates. The treatments were: fertilizers with different nutrient compositions, being, T1: formulated mix containing N, P and K, using as sources urea, monoammonium phosphate, and potassium chloride respectively; T2: biostimulant 1 with auxin; T3: biostimulant 2 with fulvic acids and inositol; T4: biostimulant 3 with organic carbon; T5: zinc sulfate, and T6: distilled water (control). Root length and root dry mass were not affected by the treatments applied in pepper and tomato seedlings. Stem diameter, length, and dry mass, and the number of leaves were superior in pepper when NPK or zinc sulfate was applied. The same variables were superior in industrial tomato when NPK or biostimulant 3 (organic carbon) was applied. The results found indicated that amendments can be used to produce more vigorous pepper and industrial tomato seedlings.
\end{abstract}

Keywords: Capsicum; Solanum lycopersicum; Mineral fertilizer; Organic matter; Auxin.

\section{Resumo}

Reguladores de crescimento como os bioestimulantes podem promover mudanças positivas nos processos fisiológicos das plantas, sendo alternativas para auxiliar no desenvolvimento de mudas com alta qualidade. Portanto, o presente estudo tem como objetivo avaliar as características de mudas de tomate industrial e pimentão adubadas com bioestimulantes. O delineamento experimental foi em blocos casualizados com seis tratamentos e quatro repetições. Os tratamentos foram: fertilizantes com diferentes composições de nutrientes, sendo, T1: mistura formulada contendo N, P e K, utilizando como fontes uréia, fosfato monoamônio e cloreto de potássio respectivamente; T2: bioestimulante 1 com auxina; T3: bioestimulante 2 com ácidos fúlvicos e inositol; T4: bioestimulante 3 com carbono orgânico; T5: sulfato de zinco e T6: água destilada (controle). O comprimento e a massa seca da raiz não foram afetados pelos tratamentos aplicados nas mudas de pimentão e tomate industrial. O diâmetro, comprimento e massa seca do caule e o número de folhas foram superiores em pimentão quando aplicados NPK ou sulfato de zinco. As mesmas variáveis foram superiores no tomate industrial quando NPK ou bioestimulante 3 (carbono orgânico) foi aplicado. Os resultados encontrados indicaram que os bioestimulantes podem ser usados para produzir mudas mais vigorosas de pimentão e tomate industrial.

Palavras-chave: Capsicum; Solanum lycopersicum; Fertilizante mineral; Matéria orgânica; Auxinas. 
Research, Society and Development, v. 10, n. 4, e19910411197, 2021

(CC BY 4.0) | ISSN 2525-3409 | DOI: http://dx.doi.org/10.33448/rsd-v10i4.11197

\section{Resumen}

Los reguladores del crecimiento como los bioestimulantes pueden promover cambios positivos en los procesos fisiológicos de la planta, siendo alternativas para ayudar al desarrollo de plántulas con alta calidad de plántulas. Por tanto, este estudio tiene como objetivo evaluar las características de plántulas de tomate industrial y pimiento fertilizadas con bioestimulantes. El diseño experimental fue un diseño de bloques al azar con seis tratamientos y cuatro repeticiones. Los tratamientos fueron: fertilizantes con diferentes composiciones de nutrientes, siendo, T1: mezcla formulada que contiene $\mathrm{N}$, P y K, utilizando como fuentes urea, fosfato monoamónico y cloruro potásico respectivamente; T2: bioestimulante 1 con auxina; T3: bioestimulante 2 con ácidos fúlvicos e inositol; T4: bioestimulante 3 con carbono orgánico; T5: sulfato de zinc y T6: agua destilada (control). El largo de la raíz y la masa seca de la raíz no se vieron afectados por los tratamientos aplicados en plántulas de pimiento y tomate. El diámetro, longitud y masa seca del tallo y el número de hojas fueron superiores en pimiento cuando se aplicó NPK o sulfato de zinc. Las mismas variables fueron superiores en tomate industrial cuando se aplicó NPK o bioestimulante 3 (carbono orgánico). Los resultados encontrados indicaron que las enmiendas se pueden utilizar para producir plántulas de pimiento y tomate industrial más vigorosas.

Palabras clave: Capsicum; Solanum lycopersicum; Fertilizante mineral; Materia orgánica; Auxin.

\section{Introduction}

Tomatoes and tomato-based products are a rich source of potassium, folate, vitamin $\mathrm{C}$ and $\mathrm{E}$, phenolic compounds, and lycopene - consistently associated with a lower risk of cancers and incidence of coronary heart disease (Vallverdú-Queralt et al., 2012; Ilupeju et al., 2015). The Capsicum genus includes the peppers, which are worldwide medicines, ornamentals, vegetables, and critical components of many food dishes (Hulse-kemp et al., 2016; Chaki et al., 2015). Peppers have a pungent alkaloid with many biological and pharmacological effects - cardioprotective, antilithogenic, antiinflammatory, analgesic, thermogenic, cancer prevention, weight loss, and gastric ulcers healing (Srinivasan et al., 2016; Kim et al., 2016).

The knowledge about physiological maturity, phenological cycle combined with appropriated crop growing conditions (temperature, humidity, irrigation, soil fertility, etc.) can improve the Solanaceae agribusiness (Costa et al., 2017), and provide food with advantages for human health. The germination and seedling early development are affected by the composition of the substrate, which must be formulated according to the requirements of each specie (Costa et al., 2017).

Plant growth regulators, also known as biostimulants, change plant physiological processes, are alternatives that can help the seedlings development with high seedlings quality (Ribeiro et al., 2017). These products may contain elaborate rates of fertilizers, soil conditioners, rhizobacteria, humic substances, and plant hormones (Hernández-Herrera et al., 2014; Olivares et al., 2015). The global demand for plant biostimulants is rapidly growing. Biostimulant composition can include substances and, or, microorganisms that are intended to stimulate natural plant processes to improve nutrient uptake, nutrient efficiency, tolerance to abiotic stress, crop quality (Wong et al., 2015), and to allow rapid recovery after stress conditions (Souza Neta et al., 2018).

Biostimulants can include many categories of compounds, such, humic and fulvic acid, protein hydrolysates, N-containing compounds, seaweed and botanical extracts, chitosan, biopolymers, inorganic compounds, and beneficial microorganisms (Wong et al., 2015). The use of biostimulants in the plant early stages can also increase resistance to pests and diseases and the fast establishment of plants, which can increase nutrients absorption and yield (Lana et al. 2009; Baldotto \& Baldotto, 2014a, 2014b). Reis et al. (2019) also observed increased plant improvement with different types of substrates in the production of pansy seedlings (Viola tricolor var. hortensis).

Despite the relevant aspects of seedling production for crop development, papers with an emphasis on seedling production are less evident (Oliveira et al., 2016, 2017). Also, the individual compounds of biostimulants can interact with other nutrients and metabolic products, resulting in difficult to predict effects without controlled studies (Parađiković et al., 2018). Therefore, this study aims to evaluate the characteristics of seedlings of pepper and industrial tomato fertilized with biostimulants. 


\section{Material and Methods}

The first experiment was carried out between March and April 2014, with tomato (Solanum lycopersicum) and the second between May and June of 2014, with pepper seeds (Capsicum annuum). The experiment was conducted in a greenhouse at the Institute of Agricultural Sciences (ICIAG) of the Federal University of Uberlândia (UFU).

The experimental design was a randomized block design with six treatments and four replicates. The treatments were fertilizers with different compositions of nutrients, being: T1 - a formulated mix containing nitrogen, phosphorus and potassium (NPK), using as sources monoammonium phosphate, potassium chloride and urea, respectively; T2- biostimulant 1: with auxin; T3 - biostimulant 2: with fulvic acids and inositol; T4 - biostimulant 3: with organic carbon; T5 - zinc sulfate and T6 - distilled water (control).

Descriptions of each treatment and their concentrations are described in Table 1. The treatments were assembled in order to compare the effect of the organic components of the biostimulants. Treatments T1 and T2 have the same amounts of N, P and K, and $\mathrm{T} 2$ presents $400 \mathrm{ppm}$ of auxin (growth-promoting hormone and cell growth). T3 and T5 present the same levels of zinc, a key element of the growth hormones synthesis and cell division in the plants, and T3 also contains 4,6\% of fulvic acids and inositol, having these stimulating functions on vegetables and acting as physical conditioners of the root environment. T4 treatment has the highest concentration of potassium, an important nutrient in plant growth, as well as organic carbon, which is related to organic matter and its benefits.

Table 1. Description of treatment composition and the amount of nutrients applied at each treatment at each application.

\begin{tabular}{cccc}
\hline Treatment & Product & Composition & Amount to each treatment \\
\hline T1 & NPK & $9 \% \mathrm{~N}, 19.64 \% \mathrm{P}, 0.83 \% \mathrm{~K}$ & $0.0334 \mathrm{~g} \mathrm{Urea} ; 1.5 \mathrm{~g} \mathrm{MAP} * ; 0.22 \mathrm{~g} \mathrm{KCl}$ \\
T2 & Biostimulant 1 & $9 \% \mathrm{~N}, 19.64 \% \mathrm{P}, 0.83 \% \mathrm{~K}, 400 \mathrm{ppm}$ de auxin & $2.0 \mathrm{~g}$ \\
T3 & Biostimulant 2 & $5 \% \mathrm{~S}, 5 \% \mathrm{Zn}, 4.6 \%$ fulvic acid, inositol, & $0.32 \mathrm{~mL}$ \\
T4 & Biostimulant 3 & $5 \% \mathrm{~N}, 6.23 \% \mathrm{~K}+$ organic carbon & $0.32 \mathrm{~mL}$ \\
T5 & Zinc Sulfate & $2.5 \% \mathrm{~S}, 5 \% \mathrm{Zn}$ & $0.0785 \mathrm{~g}$ \\
T6 & Control & --- & --- \\
\hline
\end{tabular}

MAP: monoammonium phosphate; $\mathrm{KCl}$ : potassium chloride. Source: Authors.

The solutions were prepared in the laboratory using distilled water. The NPK solution was prepared using $7.5 \mathrm{~g}$ of monoammonium phosphate, $1.1 \mathrm{~g}$ of potassium chloride and $0.167 \mathrm{~g}$ of urea in $1.0 \mathrm{~L}$ of distilled water. The biostimulant 1 solution was prepared using $10.0 \mathrm{~g}$ of the commercial product diluted in $1.0 \mathrm{~L}$ of distilled water. The biostimulant 2 solution was prepared using $1.6 \mathrm{~mL}$ of the commercial product in $1.0 \mathrm{~L}$ of distilled water. The biostimulant 3 solution was prepared using $1.6 \mathrm{~mL}$ of the commercial product in $1.0 \mathrm{~L}$ of distilled water. The zinc sulfate solution was prepared using $0.3925 \mathrm{~g}$ in $1.0 \mathrm{~L}$ of distilled water.

Commercial substrate (Carolina ${ }^{\circledR}$ Standard) with coconut fiber, vermiculite, limestone, and traces of NPK was used, which was distributed in 128 cells isoprene trays ( 16 rows with 8 cells each). Each plot was composed of 16 cells ( 2 rows of 8 cells). Two seeds were sown on each cell at $1.0 \mathrm{~cm}$ depth, thinning to one seedling after plant emergency. A total of 64 cells per treatment and 384 cells per experiment (pepper and industrial tomato). The treatments were separated by an empty row of cells used as a border. The trays were irrigated twice a day during the whole experimental period. The applications of the treatments occurred about 3 and 4 weeks after sowing. 
The solutions were applied using a $10 \mathrm{~mL}$ syringe, being $3.1 \mathrm{~mL}$ per cell/seedling. All treatments were applied using the same amount of solution. Seedlings were taken out 34 days after sowing for measuring their characteristics. All plants were harvested and washed in running water to remove the product and substrate from the roots. Soon after the washing process, shoot length, root length, stem diameter, root dry mass and shoot dry mass were measured.

The shoot and root length were measured with a ruler scaled in millimeters. A digital caliper was used to measure the shoot diameter. The shoot and root dry mass were obtained, splitting the plants into roots and shoots, placing in paper bags after, and dried at $65{ }^{\circ} \mathrm{C}$ for 72 hours. After drying, roots and shoots were weighed using a digital scale with a precision of two decimals.

Data were submitted to analysis of variance (ANOVA) on statistical software SISVAR and the means were compared by Tukey's test, at 0.05 significance.

\section{Results and Discussion}

In tomato, the shoot diameter (SD) did not differ between treatments. The number of leaves (NoL) showed higher values with NPK application, but equal to biostimulant 3 and Control treatments. Biostimulant 3 induced the bigger shoot length (SL); however, the results were similar to NPK, zinc sulfate and control. Shoot dry mass (SDM) did not differ between treatments. Thus, treatments with NPK and biostimulant 3 obtained the highest averages in all variables analyzed, as well as the control (Table 2).

Table 2. Characteristics evaluated on tomato and pepper experiments.

\begin{tabular}{|c|c|c|c|c|c|c|c|}
\hline Plant specie & Treatment & SD & NoL & RL & SL & SDM & RDM \\
\hline \multirow{6}{*}{ Pepper } & NPK & $1.96 \mathrm{a}$ & $4.96 \mathrm{a}$ & $7.11 \mathrm{a}$ & $9.92 \mathrm{a}$ & $0.87 \mathrm{a}$ & $0.19 \mathrm{a}$ \\
\hline & Biostimulant 1 & $1.66 \mathrm{ab}$ & $4.15 \mathrm{~b}$ & $6.44 \mathrm{a}$ & $8.45 \mathrm{a}$ & $0.77 \mathrm{ab}$ & $0.20 \mathrm{a}$ \\
\hline & Biostimulant 2 & $1.56 \mathrm{~b}$ & $4.37 \mathrm{ab}$ & $6.92 \mathrm{a}$ & $8.09 \mathrm{a}$ & $0.72 \mathrm{ab}$ & $0.19 \mathrm{a}$ \\
\hline & Biostimulant 3 & $1.55 \mathrm{~b}$ & $4.09 \mathrm{~b}$ & $6.24 \mathrm{a}$ & $8.10 \mathrm{a}$ & $0.59 \mathrm{~b}$ & $0.19 \mathrm{a}$ \\
\hline & Zinc Sulfate & $1.79 \mathrm{ab}$ & $4.71 \mathrm{ab}$ & $7.52 \mathrm{a}$ & $9.05 \mathrm{a}$ & $0.72 \mathrm{ab}$ & $0.15 \mathrm{a}$ \\
\hline & Control & $1.70 \mathrm{ab}$ & $4.50 \mathrm{ab}$ & $7.30 \mathrm{a}$ & $8.81 \mathrm{a}$ & $0.78 \mathrm{ab}$ & $0.17 \mathrm{a}$ \\
\hline \multirow{6}{*}{ Tomato } & NPK & $2.69 \mathrm{a}$ & $4.18 \mathrm{a}$ & $10.02 \mathrm{a}$ & $19.36 \mathrm{ab}$ & $2.05 \mathrm{a}$ & $0.63 \mathrm{a}$ \\
\hline & Biostimulant 1 & $2.64 \mathrm{a}$ & $3.68 \mathrm{bc}$ & $10.22 \mathrm{a}$ & $16.94 \mathrm{ab}$ & $1.55 \mathrm{~b}$ & $0.53 \mathrm{a}$ \\
\hline & Biostimulant 2 & $2.69 \mathrm{a}$ & $3.15 \mathrm{~d}$ & $10.26 \mathrm{a}$ & $15.10 \mathrm{~b}$ & $1.51 \mathrm{~b}$ & $0.45 \mathrm{a}$ \\
\hline & Biostimulant 3 & $2.86 \mathrm{a}$ & $3.96 \mathrm{ab}$ & $10.74 \mathrm{a}$ & $20.32 \mathrm{a}$ & $2.26 \mathrm{a}$ & $0.67 \mathrm{a}$ \\
\hline & Zinc Sulfate & $2.60 \mathrm{a}$ & $3.53 \mathrm{~cd}$ & $11.20 \mathrm{a}$ & $18.09 \mathrm{ab}$ & $1.98 \mathrm{ab}$ & $0.58 \mathrm{a}$ \\
\hline & Control & $2.81 \mathrm{a}$ & $3.83 \mathrm{abc}$ & $11.12 \mathrm{a}$ & $20.22 \mathrm{a}$ & $2.28 \mathrm{a}$ & $0.59 \mathrm{a}$ \\
\hline
\end{tabular}

${ }^{1}$ Means followed by the same letter do not differ, inside each experiment, according to Tukey's test, at 0,05 of significance. SD: stem diameter (mm); NoL: number of leaves; RL: root length; SL: shoot length; SDM: shoot dry mass; RDM: root dry mass. Source: Authors.

In pepper, shoot diameter (SD) was higher in NPK treatment, not differing; however, from Zinc Sulfate, Control, and biostimulant 1 (Table 2). The number of leaves (NoL) was higher with NPK application, not differing from zinc sulfate, biostimulant 3 and Control. Shoot length (SL) did not differ for the products applied. Shoot dry mass (SDM) was higher in the NPK treatment, not differing from biostimulant 1, biostimulant 3, zinc sulfate and control. In this way, the treatments with NPK and Zinc Sulfate obtained the highest averages in all variables analyzed, as well as the Control, having them all statistically the same average values.

In both experiments, the root length (RL) and root dry mass (RDM) did not differ between the treatments (Table 2). 
Research, Society and Development, v. 10, n. 4, e19910411197, 2021

(CC BY 4.0) | ISSN 2525-3409 | DOI: http://dx.doi.org/10.33448/rsd-v10i4.11197

The seedling production seeks to obtain greater shoot and root lengths, number of leaves and shoot diameter. Different compounds added to the substrate could influence these characteristics on tomato seedlings. Several organic compounds, as well as different mixtures of mineral fertilizers, have been tested and the results are varied, which often leads to questions about the dose applied, as well as the effect of the elements on the plant's physiology.

Among the products used, biostimulant 3 and biostimulant 2 present on their composition organic carbon, which is referred by Medeiros et al. (2013) as favoring the production of dry mass of shoots and roots. These authors also mention that a general tendency to compose substrates for the production of seedlings has been the addition of organic matter, which contributes not only to the nutrient supply but also to the physicochemical substrate characteristics. In these experiments, biostimulant 3 was the best treatment for tomato seedlings production, favoring mainly the root and shoot sizes and dry mass. In pepper seedlings, there was no positive effect on the use of this product or the other biostimulant, biostimulant 2, and biostimulant 1 .

Ferreira et al. (2014) related significant differences in the characteristics of tomato seedlings when the proportion of organic compounds on the substrate (cattle manure and small ruminants) varied, being the best proportion $30 \%$ of cattle manure and $70 \%$ small ruminants manure. Barros et al. (2014) concluded that filter residue substrates had positive effects on the production of industrial tomato seedlings.

Biostimulants 3 and biostimulant 2 contain humic and fulvic acids in their composition. Only biostimulant 3 affected tomato seedlings but did not differ from the Control treatment. Corroborating with the data of this study, Azevedo et al. (2011) did not obtain significant effects for the content of chlorophyll, calcium, and seedling growth using fulvic and humic acids on the tomato seedling's production.

Zinc has an important role as an enzymatic activator and an essential nutrient to the growth of plants. Benicio et al. (2011) studied the effect of biofertilizers based on fresh marine fish and sugar cane with zinc, copper and iron in tomato seedlings. It was concluded that this mix provided better growth of the seedlings, with a $6 \%$ increase in the fresh mass. Zinc sulfate was also among the best treatments in the present study, except for the number of leaves in tomato.

The best treatments in both experiments were not superior to the control treatment in any of the evaluated characteristics. It is understood that the substrate used is formulated with a substantial quantity of necessary to the initial growth of the seedlings. The authors also emphasize the evaluation period - only at the seedling stage of the plant. It was not evaluated the effect of the treatments throughout the cycle of the plants since the applications of some of the treatments are recommended throughout the crop cycle.

Moreover, the use of plant hormones needs to be careful, since the excess nutrients and phytohormones can cause toxicity to the plant, affecting the cellular metabolism and the initial development of seedlings (Castro et al., 2017).

\section{Conclusions}

Root lenght and root dry mass were not affected by the biostimulant applied to pepper and industrial tomato seedlings.

Stem diameter, length, and dry mass, and the number of leaves were superior in pepper when NPK or zinc sulfate was applied.

Stem diameter, length, and dry mass, and the number of leaves were superior in industrial tomato when NPK or biostimulant 3 (organic carbon) was applied 
Research, Society and Development, v. 10, n. 4, e19910411197, 2021

(CC BY 4.0) | ISSN 2525-3409 | DOI: http://dx.doi.org/10.33448/rsd-v10i4.11197

\section{Acknowledgments}

The authors wish to thank the Conselho Nacional de Desenvolvimento Científico e Tecnológico (CNPq), Coordenação de Aperfeiçoamento de Pessoal de Nível Superior (CAPES) and Fundação de Amparo à Pesquisa do Estado de Minas Gerais (FAPEMIG) for the financial support.

\section{References}

Azevedo, S. A., Morais, J., Oliveira, R. A., Sousa, V. M. S., Nascimento, I. O., Dias, V. L. N., \& Nunes, S. E. A. (2011). Efeitos dos ácidos húmicos e fúlvicos na qualidade da Lactuca sativa L. (alface) em relação às concentrações de clorofila e teor de cálcio e magnésio. http://www.abq.org.br/cbq/2011/trabalhos/5/5-4507158.htm

Baldotto, M. A., \& Baldotto, L. E. B. (2014a). Ácidos Húmicos. Revista Ceres, 61, 856-881.

Baldotto, L. E. B., \& Baldotto, M. A. (2014b). Adventitious rooting on the Brazilian red-cloak and sanchezia after application of indole-butyric and humic acids Horticultura Brasileira, 32(4), 434-439. http://dx.doi.org/10.1590/S0102-053620140000400010

Barros, P. C. S., Costa, A. R., Silva, P.C., Costa, R. A. (2014). Torta de filtro como biofertilizante para produção de mudas de tomate industrial em diferentes substratos. Revista Verde de Agroecologia e Desenvolvimento Sustentável, 9, 270.

Benício, L. P. F., Silva, L. L., Lima, S. O. (2011). Produção de mudas de couve sob efeito de diferentes concentrações de biofertilizantes. Revista ACTA Tecnológica, 6(2),1-6. http://dx.doi.org/10.35818/acta.v6i2.67

Castro, D. G., Bruzi, A. T., Zambiazzi, E. V., de Rezende, P. M., Zuffo, A. M., Ana, P., \& Bianchi, M. C. (2017). Qualidade fisiológica e expressão enzimática de sementes de soja RR®. Revista de Ciências Agrárias, 40(1), 222-235. https://doi.org/10.19084/RCA16054

Chaki, M., Morales, P. A., Ruiz, C., Begara-Morales, J. C., Barroso, J. B., Corpas, F. J., \& Palma, J. M. (2015). Ripening of pepper (Capsicum annuum) fruit is characterized by an enhancement of protein tyrosine nitration. Annals of Botany, 116(4), 637-647. https://doi.org/10.1093/aob/mcv016

Costa, F. C. L., Silva, F. R. B., Silveira, A. T. L., Uchôa, K. S. A., Deus, M. V. C., \& Silva, M. M. (2017). Doses of organic substrate in the production of red chili pepper seedlings. Revista Internacional de Ciências, 7 (1), 22-31. https://doi.org/10.12957/ric.2017.25135

Ferreira, L. L., Almeida, A. E. S., Costa, L. R., Medeiros, J. F., \& Porto, V. C. N. (2014). Vermicomposto como substrato na produção de mudas de tomate (Lycopersicon esculentum) e couve-folha (Brassica oleracea var. acephala). Revista Verde de Agroecologia e Desenvolvimento Sustentável, 9 (2), 256-263.

Hernández-Herrera, R. M., Santacruz-Ruvalcaba, F., Ruiz-López, M. A., Norrie, J., \& Hernández-Carmona G. (2014). Effect of liquid seaweed extracts on growth of tomato seedlings (Solanum lycopersicum L.). Journal of Applied Phycology, 26(1), 619-628. https://doi.org/10.1007/s10811-013-0078-4

Hulse-Kemp, A. M., Ashrafi, H., Plieske, J., Lemm, J., Stoffel, K., Hill, T., Luerssen, H., Pethiyagoda, C. L., Lawley, C. T., Ganal, M. W., \& Deynze, A. V. A. (2016). HapMap leads to a Capsicum annuum SNP infinium array: a new tool for pepper breeding. Horticulture Research, 3, 1-10. https://doi.org/10.1038/hortres.2016.36

Ilupeju, E. A. O., Akanbi, W. B., Olaniyi, J. O., Lawal, B. A., Ojo, M. A., \& Akintokun, P. O. (2015). Impact of organic and inorganic fertilizers on growth, fruit yield, nutritional and lycopene contents of three varieties of tomato (Lycopersicon esculentum (L.) Mill) in Ogbomoso, Nigeria. African Journal of Biotechnology, 14(31), 2424-2433. https://doi.org/10.5897/AJB10.1902

Kim, H.-G., Bae, J.-H., Jastrzebski, Z., Cherkas, A., Heo, B. G., Gorinstein, S., \& Ku, Y.-G. (2016). Binding, Antioxidant and Anti-proliferative Properties of Bioactive Compounds of Sweet Paprika (Capsicum annuum L.). Plant Foods for Human Nutrition, 71 (2), 129-136. https://doi.org/10.1007/s11130-016-0550-9

Lana, A. M. Q., Lana, R. M. Q., Gozuen, C. F., Bonotto, I., \&Trevisan, L. R. (2009). Aplicação de reguladores de crescimento na cultura do feijoeiro. Bioscience Journal, 25, 13-20.

Medeiros, D. C., Azevedo, C. M. S. B., Sousa, R. A., Oliveira, C. J., \& Marques, L. F. (2013). Qualidade de mudas de tomate em função do substrato e irrigação com efluentes de piscicultura. Revista Brasileira de Ecologia, 892, 170-175.

Olivares, F. L., Aguiar, N. O., Rosa, R. C. C., \& Canellas, L. P. (2015). Substrate biofortification in combination with foliar sprays of plant growth promoting bacteria and humic substances boosts production of organic tomatoes. Scientia Horticulturae, 183, 100-108. https://doi.org/10.1016/j.scienta.2014.11.012

Oliveira, F. A., Oliveira, J. M., Souza Neta, M. L., Oliveira, M. K. T., \& Alves, R. C. (2017). Substrato e bioestimulante na produção de mudas de maxixeiro. Horticultura Brasileira, 35(1), 141-146. https://doi.org/10.1590/s0102-053620170122

Oliveira, M. K. T., Martins, D. C., Souza Neta, M. L., Medeiros, J. F. (2016). Produção de mudas de cultivares de maxixeiro em fibra de coco fertirrigadas com diferentes concentrações de nutrients. Revista Ceres, 63(5), 698-705.

Parađiković, N., Teklić, T., Zeljković, S., Lisjak, M., \& Špoljarević, M. (2018). Biostimulants research in some horticultural plant species - A review. Food and Energy, 8, 1-17. https://doi.org/10.1002/fes3.162 
Research, Society and Development, v. 10, n. 4, e19910411197, 2021

(CC BY 4.0) | ISSN 2525-3409 | DOI: http://dx.doi.org/10.33448/rsd-v10i4.11197

Ribeiro, R. F., Lobo, J. T., Cavalcante, I. H. L., Tenreiro, I. T. G., LIMA, D. D. (2017). Bioestimulante na produção de mudas de videira cv. Crimson seedless. Scientia Agricola, 18(4), 36-42.

Reis, B. B., Rodrigues, D. B., Almeida, A. S., Chagas, H. L., Suné, A. S., Geweher, E., Nunes, C. A., Peres, A. A.O., Konzen, L., Rodrigues, G. F., Assis, A. M., \&Tunes, L. V. M. (2019). Substrates and Sowing Depths in the Production of Pansy Seedlings (Viola tricolor L.). Journal of Agricultural Science, 11(16), 159-167. https://doi.org/10.5539/jas.v11n16p159

Srinivasan, K. (2016). Biological Activities of Red Pepper (Capsicum аnnиum) and Its Pungent Principle Capsaicin: A Review. Critical Reviews in Food Science and Nutrition, 56(9), 1488-500. https://doi.org/10.1080/10408398.2013.772090

Souza Neta, M. L., Oliveira, F. .A, Torres, S. B., Souza, A. A. T., Silva, D. D. A, \& Santos S. T. (2018). Gherkin cultivation in saline medium using seeds treated with a biostimulant. Acta Scientarum Agronomy, 40, e35216. https://doi.org/10.4025/actasciagron.v40i1.35216

Vallverdú-Queralt, A., Medina-Remón ,A., Casals-Ribes, I., Andres-Lacuev, C., Waterhouse, A. L., \& Lamuela-Raventos, R. M. (2012). Effect of tomato industrial processing on phenolic profile and hydrophilic antioxidant capacity. LWT - Food Science and Technology, 47(1), 154-160. https://doi.org/10.1016/j.lwt.2011.12.020

Wong, W. S., Tan, S. N., Ge, L., Chen, X., \& Yong, J. W. H. (2015). The importance of phytohormones and microbes in biofertilizers. In Bacterial Metabolites in Sustainable Agroecosystem, D.K. Maheshwari, ed. (Springer International Publishing), 105-158. 10.1007/978-3-319-24654-3_6 